\title{
AQUATIC PARK PROPOSAL FOR LAKE WINNIPEGOSIS, KAWINAW AND PELICAN LAKES
}

\author{
By Kees Vermeer, Canadian Wildlife Service, Edmonton
}

In the summer of 1969 , I surveyed colonies of White Pelicans, Doublecrested Cormorants and Great Blue Herons by float plane in Manitoba. Lake Winnipegosis, Kawinaw and Pelican Lakes (Fig. 1) impressed me as having the richest avifauna for those species in the Canadian prairie provinces. Lake Winnipegosis, with 1,403 nests of Double-crested Cormorants (Vermeer, 1969a), has as many cormorants breeding there as in the provinces of Alberta (Vermeer, 1969b) and Saskatchewan (Vermeer, in press, a) combined. Great Blue Heron colonies were also observed to be more numerous at Lake Winnipegosis than at any other lake in the prairie provinces (Vermeer, 1969 c; 1970; and unpublished observations for Sas-

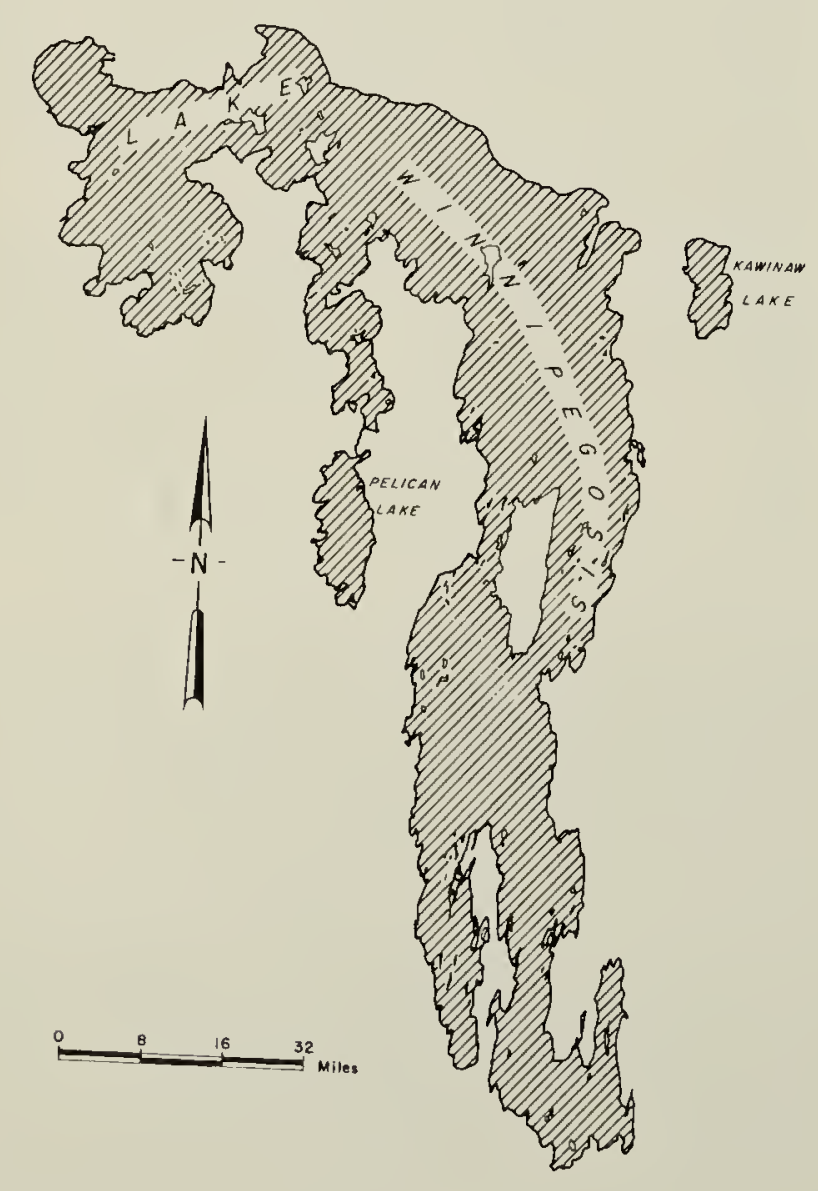

Fig. 1 Lake Winnipegosis, Kawinaw and Pelican lakes, Manitoba katchewan). Pelican Lake with 1,670 nests and Kawinaw Lake with 1,560 nests of White Pelicans in 1969 possess the second and third largest colonies for that species in Canada, while Lake Winnipegosis has a pelican colony with 410 nests (Vermeer, in prep.). Besides herons, pelicans, and cormorants, numerous colonies of California Gulls, Herring Gulls, Ringbilled Gulls, Caspian Terns and Common Terns breed on islands in these lakes. Many of the above species breed in association with one another. Figure 2, for example, shows an island in Kawinaw Lake, where Ring-billed Gulls, Common Terns, White Pelicans, and Double-crested Cormorants nest on the ground, where Great Blue Herons nest in trees and where many Western Grebes nest in the marshy areas of the island. Canada Geese and White-winged Scoters also breed on that island.

Pelican and cormorant colonies have been declining in number in the prairie provinces, apparently because of human disturbance (V ermeer, 1969a; 1969b; in press; in prep.). Protection is urged for at least the major breeding colonies at Pelican and Kawinaw lakes. It is especially urgent for the latter as a new road, number 327 , between highway number 6 and Easterville, provides easy access for the launching of power boats. Invasion by boats and frequent visits to the colony will cause the birds to leave their eggs which then become susceptible to extensive predation by Herring Gulls which nest on another island in that lake. It is only a matter of time before bird colonies at Pelican Lake and Lake Winnipegosis will be accessible to many tourists. Drent and Guiguet (1961:123), in a plea for protection of sea-bird colonies along the British Columbia Coast, state in this 
